NEW LITERARIA-

An International Journal of Interdisciplinary Studies in Humanities

Volume 2, No. 1, January-February, 2021, PP. 210-216

ISSN: 2582-7375

DOI: https://dx.doi.org/10.48189/nl.2021.v02i1.023

www.newliteraria.com

\title{
"In Nature There is Nothing Melancholy": Romantic Poetry and Selfish Constructions of Nature and Sadness
}

\author{
Tyler Martin Sehnal
}

\begin{abstract}
Renowned Romantic poets like William Wordsworth, Charlotte Turner Smith, and John Clare were obsessed with love, human emotions, and how the natural world works to influence and inspire these sensations of the human experience. Common muses featured in these authors' works often include bodies of water-such as the River Wye, which inspired William Wordsworth - or animals - like the nightingale, a creature which inspired many poets including Charlotte Smith and Samuel Coleridge to write such poems as Smith's "To a Nightingale." In using these muses to construct nature, most Romantic poets played with the idea that the natural world could positively or negatively influence a person's psyche. In short, through their work, Romantic poets tended to make a point of explaining how scenes like the River Wye or the nightingale or a sunny Spring day affected their own perceptions of the human experience; however, some other poets, opposing this entwinement between human and nature, offered another view. Pieces like John Clare's "The Nightingale's Nest" and Samuel Coleridge's "The Nightingale" sought to paint nature and the human experience as separate entities, thus exposing the practice of linking the two as a selfish one, particularly in the case of Wordsworth and Smith, who Clare and Coleridge's pieces suggested had a habit of selfishly constructing nature as a serene, peaceful and unassuming presence merely as a means to highlight their own unhappiness.
\end{abstract}

Keywords: Romanticism, Sorrow, Poetry, Selfishness, Interplay.

\section{Introduction}

In a review of M. H. Abrams' "Structure and Style in the Greater Romantic Lyric," Harvard University's John Koelzer points out Abrams' belief that to label Romantic poems as "simply nature lyrics is not only inadequate, but radically misleading" (2006, p. 67). Rather, Koelzer synthesizes that Romantic poetry is typically organized not merely by "a series of perceptions," but is characterized by a "complex process of perception, recollection, and association whereby 'the lyric speaker achieves an insight"' (p. 68). However, Abrams' essay-as Koelzer explains - also mentions that in a lot of Romantic poetry, this "process" is "sstructurally subordinate to the [speaker's] meditation, and the meditation is sustained, continuous, and highly serious'... the greater Romantic lyric is defined by its 'repeated outin-out process, in which mind confronts nature and their interplay constitutes the poem"' ( $\mathrm{p}$. 68). The idea of "interplay" seems to be inherently self-serving, as it often involves imposing one's own melancholy onto the natural world, allowing the poet to declare nature as a passive thing that is both impressionable and capable of mirroring human emotions.

In works by renowned Romantic poets like William Wordsworth and Charlotte Smith, 
this "interplay" between human consciousness and nature is obvious, and its selfish implications are clear in how the two poets use nature as a means to conceptualize their own emotions. In this article, I will explain how poets like Wordsworth, Smith, and John Keats use this technique of "interplay" discussed by Abrams in his "Structure and Style" essay (specifically, in a way that is inherently dismissive of nature's autonomy and instead paints nature as little more than a tool for expressing and conceptualizing human emotion, often through the use of juxtaposition). I will also examine how poems by John Clare and Samuel Coleridge expose a discourse among Romantic poets regarding nature's role in Romantic poetry by reviewing how these poets distinguish nature from humanity and the human consciousness, thus illuminating Wordsworth, Smith, and other Romantics' selfish appropriation of nature as a means to express their own displeasure, sorrow, and melancholy.

\subsection{Examining Wordsworth}

Wordsworth's "Lines Written in Early Spring," a 24-line poem about observing the start of the season, juxtaposes the serenity and pleasure of nature with the harshness of the human experience from start to finish. For example, Wordsworth often couples vivid scenes with interpersonal and emotional turmoil: "while in a grove I sat reclined / in that sweet mood when pleasant thoughts / bring sad thoughts to mind" (Wordsworth, 1798, lines 1-4) and later, "the budding twigs spread out their fans... there was pleasure there... have I reason not to lament what man has made of man?" (Wordsworth, 1798, lines 21-24) In these lines, Wordsworth constructs nature as almost inseparable from human emotion by intertwining the two, presenting sadness and melancholy as a direct response to nature's serenity and playfulness. It is clear from these lines also that Wordsworth is utilizing this "interplay" between nature and speaker that Abrams writes about as a way to discuss how the natural world finds itself working to heighten or deepen the emotional affairs of the speaker. In the final lines of the poem - in which Wordsworth suggests that it is "nature's holy plan" for him to perceive the natural world as pleasurable and that perhaps he ought to feel as though the human experience pales in comparison - the poet seems to reiterate that nature exists solely to inspire such comparison and contemplation of human evil and arrogance.

According to the University of Montana's James McKusick, author of a piece entitled, "The Return of the Nightingale," critics typically consider Wordsworth's "Lines Written in Early Spring" to be a "dogmatic display of ingenuous nature worship." (McKusick, 2007, p. 34). McKusick also explains that perhaps Wordsworth's "ingenuous nature worship" is best demonstrated in Karl Kroeber's book, Ecological Literary Criticism, in which Kroeber labels "Lines Written" as a poem that "challenges our learned cultural presupposition that human consciousness alienates us from physical nature," and one that exposes a truth that our "selfinjuries may be rooted in a miseducation of ourselves away from linkages through pleasure with beneficent natural processes" (Kroeber, 2006, p. 34). Essentially, McKusick and Kroeber argue that while Wordsworth's poem does demonstrate a seemingly innocent appreciation of nature, the poet is - intentionally or unintentionally- selfishly intertwining his own emotions with his surroundings as a means to use nature merely as a symbol-one that demonstrates and illustrates his own unhappiness when compared to the harshness of the human experience.

John Blades' Wordsworth and Coleridge: Lyrical Ballads argues that "Lines Written" is merely another example of "Wordsworthian duality of sweet leading to sad thoughts." Specifically, Blades remarks that "Lines Written" is a poem about Wordsworth's "deeply sensitive" engagement with the pain of the human experience, an engagement spurred on by "nature's occult but penetrating action on [Wordsworth's] soul" and the "unsettling" and "solemn reminder of mortality" (Blades, 2004, p. 179) that nature and the natural world 


\section{"In Nature There is Nothing Melancholy": Romantic Poetry and Selfish Constructions of Nature and Sadness}

consistently make ever apparent: "the periwinkle trailed its wreathes" (Wordsworth, 1798, line 10). Blades explains that this theme of nature causing Wordsworth to "grieve" what "man has made of man" is also present in many of Wordsworth's other popular pieces, including "Nutting" and "The Convict." Blades explains that this phenomenon is most likely born out of Wordsworth's realization that he is "a thing of nature himself" and his belief that, like the flowers that "enjoy the air [they] breathe" (Wordsworth, 1798, lines 11-12), Wordsworth too, as a part of nature, ought to derive "benefit from" (Wordsworth, 1798, p. 180) the natural world; Wordsworth ultimately does so in using his surroundings as a means to convey his anxieties and his own unhappiness.

\subsection{Examining Smith}

Like Wordsworth, Charlotte Smith also wrote with a similar "Wordsworthian duality," particularly in pieces like her "Sonnet Written at the Close of Spring" and "On the Departure of the Nightingale" poems. Specifically, many of Smith's sonnets-namely, those published in her 1784 verse collection Elegiac Sonnets-work to "define her poetic condition negatively by contrast, that is, by defining what she is not" (Parisot, 2015, p. 661). In other words, a vast majority of Smith's work as collected in her debut book of verse juxtaposes nature's beauty and natural imagery with feelings of isolation and sadness as a means to construct human emotion. According to Bishop C. Hunt Jr., Smith was an "early influence" on Wordsworth (Wordsworth, 1970, p. 85), which is perhaps why it is unsurprising to see Smith making such a similarly consistent use of juxtaposition in her work. Like Wordsworth's "Lines Written," Smith's "Close of Spring" poem features the juxtaposition of such imagery as "Spring again call[ing] forth every bell" with the "fragility" and "fairness" of "poor humanity" (Wordsworth, 1784, lines 7-9). In using such phrasing, Smith explores nature's ability to inspire sadness in human beings, particularly when such beautiful natural imagery is compared to the "corrosive" nature of humankind.

In an article published in a 1995 issue of Women's Writing entitled, "Thorns and Roses: the Sonnets of Charlotte Smith," Deborah Kennedy explains that while many female Romantic poets of the late $18^{\text {th }}$ century often wrote melancholic poems, Smith was the one of few to direct attention to "external rather than internal factors" and imply that "it is things in the world that cause a woman to feel melancholic" more so than any sort of mental illness or other internal influence (Kennedy, 1995, p. 43). This sort of "external" influence is ever apparent in Smith's "On the Departure of the Nightingale," in which Smith suggests that the departure of the nightingale and the inability of her to hear the departed bird's song are causing her sorrow:

Sweet poet of the woods, a long adieu!

Farewell soft mistrel of the early year!

Ah! 'twill be long ere thou shalt sing anew,

And pour thy music on the night's dull ear...

The gentle bird who sings of pity best:

For still thy voice shall soft affections move,

And still be dear to sorrow and to love! (Smith, 1784, lines 1-4, 12-14)

Later, in her "Roses"article, Deborah Kennedy explains that Smith's poems, in which Smith "mourned her own self and the loss that she felt living in a life she regarded as a "rugged path"" established Smith's right to "position herself as a subject" (Kennedy, 1995, p. 43) of her poetry, thus making nature little more than a secondary presence in Smith's work. This relegation of nature to a "secondary role is also obvious in Smith's aforementioned "Close of Spring" poem: Another May new birds and flowers shall bring; / Ah! why has [my] happiness no second spring!" (Smith, 1784, lines 13-14). Thus, in highlighting herself as the center of attention and relegating nature to a supportive role, it becomes clear that the only 
purpose for the inclusion of serene, beautiful, and tranquil scenes of nature in Smith's work is so that they may exist in contrast to Smith's depression and misery. Just as in Wordsworth's poetry, it is clear that in Smith's work, the natural world is used merely to symbolize the positivity and joyous emotions that the speaker does not feel, and it is namely the interplay between nature and speaker that helps to highlight nature's secondary role as a thing that is responsible for receiving and opposing human emotions.

\subsection{Examining Clare}

While Smith and Wordsworth have historically used nature as a means to construct their own emotions, fellow Romantic poet John Clare, particularly in his poem, "The Nightingale's Nest," takes a stance far different than his Romantic counterparts. Specifically, while Wordsworth presents his emotions and sadness as inseparable from nature and Smith muses about nature merely to supplement her depictions of her own sadness, Clare's "Nightingale" poem isolates humans and nature as a means to present the two as distinctly separate forces. For example, Clare does not use such scenes as "finding a nest of oaken leaves / and eggs of paler brown" (Clare, 1835, lines 25-26) as symbols meant to represent his own feelings; rather, he merely suggests that he "loves" such scenes and distances himself from the beauty and wonder of the natural world by referring to himself and all of humankind as "strangers" (Clare, 1835, line 7). Clare also further distances himself from the forces of nature by describing the nightingale as hiding "among the greener May" and in places where "none would ever look for nests" (Clare, 1835, line 22).

According to a piece by Gary Harrison published by the Edinburgh University Press entitled, "John Clare's Poetics of Acknowledgement," Romantic poetry and nature writing in general often "immers[e] us sympathetically in... acts of affective engagement with the world." Later, in that same article, Harrison references Timothy Morton's Ecology Without Nature, a book that argues a similar point: that nature writing often is dominated by "ecomimesis" - the evocation of an author's environment-and typically "attempts to "present an original, pristine nature not "infected" with the consciousness"" (Harrison, 2012, p. 41). In his "Nightingale" poem, Clare exemplifies both of these ideas. First, Clare demonstrates an "affective engagement" with the world by explaining his love for such scenes as the nightingale's nest. Later, he expresses an interest in keeping nature "uninfected" with consciousness by labeling himself a "stranger" and by keeping such emotions as sadness and heartbreak isolated from his poetry.

To further highlight Clare's described detachment between humanity and the natural world, one could compare his "Nightingale" poem with fellow poet John Keats' "Ode to a Nightingale" poem. Specifically, a comparison between the two demonstrates that while Clare's "Nightingale" poem reads largely like an objective observation of a natural scene, Keats" "Ode" instead uses such a scene as a way to contrast his own unhappiness and disdain with the beauty and serenity of nature:

Fade far away, dissolve, and quite forget

What thou among the leaves hast never known,

The weariness, the fever, and the fret

Here, where men sit and hear each other groan;

Where palsy shakes a few, sad, last gray hairs,

Where youth grows pale, and spectre-thin, and dies;

Where but to think is to be full of sorrow

And leaden-eyed despairs,

Where Beauty cannot keep her lustrous eyes,

Or new Love pine at them beyond to-morrow. 


\section{"In Nature There is Nothing Melancholy": Romantic Poetry and Selfish Constructions of Nature and Sadness}

Away! away! for I will fly to thee... (Keats, 1819, lines 20-31)

Essentially, Keats uses the sight of the nightingale and the sound of its song as a form of escapism, suggesting that only within nature, a world "far away" from humanity, can he escape the "weariness, the fever, and the fret" of the human experience. This idea that Keats uses the scene of the nightingale as a means to "escape" is supported by an article published in 2016 by John Hopkins University Press in which author William A. Ulmer explores the idea that Keats" "Ode" provided the poet with a sort of "tragic consolation." Moreover, Ulmer explains that the nightingale's song "both ravishes the poet's senses and fills him with disquietude... the project of 'Nightingale' is both to commemorate a lapsing happiness and to ask, what then?" (Ulmer, 2016, p. 449). Therefore, while Clare suggests that he is a "stranger" within nature, Keats meanwhile expresses a desire to immerse himself in nature for the sake of exploring what he might discover beyond this "lapsing happiness." In other words, Keats' desire to use such immersion and such scenes as a means to free himself from the stress and strain of being human demonstrates that his construction of nature as a means to "escape" is entirely self-serving.

\subsection{Examining Coleridge}

Like Clare's "The Nightingale's Nest," another Romantic poet, Samuel Coleridge, seeks to distinguish the natural world from the world of humankind rather than intertwine the two in his poem "The Nightingale." While many existing texts which "provide a measure of Coleridge's interest in nature are voluminous" and present a "vastly troubled history of conflicting attitudes and uncertain aspirations," studies of Coleridge's work suggest that Coleridge's belief in the "mutual dependence of subject and object" often "reduce the spectrum of his reactions to nature" (Modiano, 1985, p. 4). However, though such discrepancies could be used to justify the apparent lack of Coleridge's selfish impositions on nature, Coleridge's "Nightingale" poem specifically disavows the concept of selfishly using nature as a means to illustrate one's emotions. For example, in lines 14 and 15 of his poem, Coleridge mocks the idea of the nightingale's song being a melancholy one: "most musical, most melancholy' bird! / A melancholy bird? Oh! Idle thought!" (1798). Later, Coleridge specifically attacks those "conceited" poets before him who have helped to play up the "stale convention of the nightingale as a symbol of melancholy" (Bernstein, 1981, p. 342):

(And so, poor wretch! filled all things with himself,

And made all gentle sounds tell back the tale

Of his own sorrow) he, and such as he,

First named these notes a melancholy strain.

And many a poet echoes the conceit. (Coleridge, 1798, lines 19-23)

Fred Randel's 1982 article "Coleridge and the Contentiousness of Nightingales" suggests that Coleridge's "Nightingale" poem represents an even broader theme of freeing nature from the confines of humanity and human influence. Specifically, Randel references research by Lorenz Eitner, which suggested that birds, caged or freed from cages, often carried ideological meanings in middle and late eighteenth-century art and literature" (p. 33). However, Randel also mentions that by the time his "Coleridge" article was published, the image of the "freed bird, perched triumphant atop a cage" had become a popular symbol of "Liberty." Further, Randel explains that research like that conducted by Eitner seems to confirm that this "libertarian impetus" seeking to "free birds from cages" was a "unifying characteristic of romanticism" and romantic poetry (p. 33). This concept of "freeing" nature is ever apparent in Coleridge's poem, in which the poet directly condemns writers like Wordsworth and Smith who defy this "libertarian impetus" by "caging" birds and nature by constructing such creatures and scenes solely within the confines and in the contexts of their own human emotions. 
Sources like Harrison, Abrams - and by extension, Koelzer-have thoroughly explored the relationship between humans and the natural world as well as have examined how this dynamic - that which either intertwines or distinguishes the human consciousness from the immaculacy of nature-is presented in the lyrics of Romantic poetry. In this essay, I have synthesized these authors' findings and, by combining them with my own comparative analyses of Wordsworth, Smith, Keats, and others' poetry as well as with similar analyses by authors like Hunt Jr., I have shed light on the origination of a historical discourse among some of the world's most prolific Romantic poets.

While it was commonplace for celebrated poets like Wordsworth, Smith, and others to selfishly construct nature as a means to illustrate their own displeasure or unhappiness (and is nowadays a practice often critiqued by scholars of these works), two of Wordsworth and Smith's counterparts-John Clare and Samuel Coleridge-originally exposed why juxtaposing nature against human emotions can be interpreted as a selfish act. How so? Both Clare and Coleridge authored a plethora of poems that paint nature and human emotion as entirely separate entities, emphasizing the self-serving nature of the idea that the natural world is in some way affected by or can somehow respond to, and even innocently oppose, human sadness. While Clare's "The Nightingale's Nest" specifically suggested that humans and their emotions ought to be considered "strangers" in a natural, foreign environment, Coleridge's "The Nightingale" suggested that humans impose their own negative emotions such as sadness on nature-a presence uncontaminated by sensations of sorrow or melancholy until these emotions are transposed on nature by human beings. Combining these two ideas put forth by Clare and Coleridge's work, one can begin to recognize the inherent egotism in humans that often manifests in poems about nature, whenever nature is written about as having a clear connection to one's emotions.

While Romantic poetry is traditionally defined by poets' intertwining of emotionality with natural settings and scenery, this practice has been considered by many to be selfcentered, particularly in the case of Romantic poets William Wordsworth and Charlotte Smith. As we have seen in Wordsworth's "Lines Written in Early Spring," the speaker intertwines his emotions and doubts on the state of humanity with his surroundings as a means to convey his concerns. Likewise, in Smith's "Sonnet Written at the Close of Spring" and "On the Departure of the Nightingale" poems, the speaker illustrates the fading beauty of a season and creature departed as a means to give reason to and highlight her own despair and sorrow. When compared against the writings of poets like John Clare or Samuel Coleridge, Wordsworth, Smith and Keats' perversion of nature through their imposition of their emotions on a world otherwise uncorrupted by melancholy or sorrow becomes clear and - by extension - their selfish appropriation of the natural world as a means to illustrate their own displeasure is illuminated.

\section{References}

Bernstein, G. M. (1981). The Recreating Secondary Imagination in Coleridge's "The Nightingale." ELH, 48(2), pp. 339-350. https://doi.org/10.2307/2872975

Blades, J. (2004). Wordsworth and Coleridge: Lyrical Ballads. Macmillan International Higher Education.

Clare, J. (1835). The Nightingale's Nest. https://www.poemhunter.com/poem/thenightingale-s-nest/

Coleridge, S. (1798). The Nightingale. http://www.online-literature.com/coleridge/642/

Harrison, G. (2012). John Clare's Poetics of Acknowledgement. Romanticism, 18(1),pp. 4154. 
"In Nature There is Nothing Melancholy": Romantic Poetry and Selfish Constructions of Nature and Sadness

Hunt Jr., C. (1970). Wordsworth and Charlotte Smith. The Wordsworth Circle, 35(2),pp. 85103.

Keats, J. (1819). Ode to a Nightingale. https://www.poetryfoundation.org/poems/44479/odeto-a-nightingale

Kennedy, D. (1995). Thorns and Roses: The Sonnets of Charlotte Smith. Women's Writing, 2(1), pp. 43-53.

Koelzer, R. (2006). Abrams among the Nightingales: Revisiting the Greater Romantic Lyric. The Wordsworth Circle, 37(2), 67-71.

McKusick, J. C. (2007). The Return of the Nightingale. The Wordsworth Circle, 38(1-2), 3440.

Modiano, R. (1985). Coleridge and the Concept of Nature. Springer.

Parisot, E. (2015). Living to Labour, Labouring to Live: The Problem of Suicide in Charlotte Smith's Elegiac Sonnets. Literature Compass, 12(12), 660-666.

Randel, F. V. (1982). Coleridge and the Contentiousness of Romantic Nightingales. Studies in Romanticism, 21(1), 33-55.

Smith, C. (1784). On the Departure of the Nightingale. https://www.poetryfoundation.org/poems/51894/on-the-departure-of-the-nightingale

Smith, C. (1784). Sonnet Written at the Close of Spring. https://poetryarchive.org/poem/sonnet-written-at-close-spring/

Ulmer, W. A. (2016). Tragic Consolation in "Ode to a Nightingale." Studies in Romanticism, 55(4), 449-469.

Wordsworth, W. (1798). Lines Written in Early Spring. https://www.poetryfoundation.org/poems/51001/lines-written-in-early-spring

\section{Bio-note}

Tyler Martin Sehnal is a student at East Carolina University and has a B.A. in English from Guilford College.

Email:sehnal72@gmail.com. 